\title{
Some Characteristics of High Level Tertiary Age Alluvial Terraces along the Orange River between the towns of Douglas and Prieska, Northern Cape Province, South Africa.
}

\author{
De Meillon, L. ' , and Bristow, J. W. ${ }^{2}$
}

1. Moonstone Diamonds, 4 Diomedes Street Kimberley, 8300, South Africa

2. Cigard Consulting, Box 11946, Hatfield, 0028, South Africa

Although the first diamond in South Africa was discovered along the Orange River, near the town of Douglas, this area has not seen the same intensity of prospecting and mining that has been the case for the lower reaches of the river. Past digging activities, recent small scale mining and modern sedimentological studies have shown that several diamondifererous terrace gravel deposits exist in the Douglas - Prieska area. Deposits exist as a series of high level terraces, typically enriched in banded ironstone clasts and overlain by Rooikoppie or derived gravels, a series of intermediate terraces, and low level terraces adjacent to the present Orange river drainage.

Past diamond mining activities in the Douglas area have been restricted mainly to the Rooikoppie or derived gravels and the younger terraces adjacent to the river. The derived gravel horisons were formed through preferential destruction of certain clasts during calcretisation. Subsequent weathering of the calcrete left a diamond bearing deposit consisting mainly of siliceous clasts and diamonds. Historical data of diamond recoveries from these derived gravel horizons indicate a significant increase in diamond recoveries from areas with a high proportion of banded ironstone clasts. Underlying gravel horisons have been exposed only at a limited number of locations.

Clast sizes noted in the high level terraces suggest deposition by a river system much larger than the present Orange with input from several drainage basins over various periods of time. Variations in clast lithologies between terraces of similar elevation suggest that the area $\sim 60 \mathrm{~km}$ west of Douglas could have been the site of the confluence of two major river systems (McCarthy, 1983). Sedimentary structures have been largely destroyed during various stages of calcretisation, though excavations made as a consequence of prospecting operations have allowed systematic studies of these deposits.

Diamond concentration in the older, high level terraces are controlled to a large degree by bedrock features and clast sizes. The bedrock of most of the terraces consists of Dwyka Tillite or shales which are generally not conducive to the entrapment of diamonds in economical exploitable quantities. At certain locations however, bedrock irregularities coupled with large clast sizes form stable trapsites. These bedrock features are generally not as spectacular as those seen lower down the Orange River and in many cases appear to be subtle and indescript. Diamond characteristics and size distributions suggest a proximal source with diamond concentration resulting from the turbulence and trapsite material introduced at the confluence of two major river systems.

Intermediate terraces in the area contain a similar percentage of banded ironstone clasts as found in the higher level terraces at certain locations, though recent small scale mining tends to indicate that these terraces generally have lower diamond grades. The lowest terraces adjacent to the present river bed 
contains a much lower percentage of banded ironstone clasts. They typically have low diamond grades but diamonds found in these deposits are typically of very high grade.

\section{References}

McCarthy, T.S., 1983, Evidence for the existence of a major, southerly flowing river in Griqualand West: Trans. Geol. Soc. S. Afr., 86 (1983), p. 37-49. 